\title{
A Mapping of Islamization of Accounting
}

\section{Nurika Restuningdiah, Vega Wafaretta, and Rizka Furqorina}

Accounting Department, Faculty of Economics, Universitas Negeri Malang

\section{Abstract}

Objective - Most scholars agree that Islamic accounting should incorporate Al-Quran and Hadith, but they have different perspectives relating to how far accounting to be Islamized. Therefore, this study aims to map the Islamization of accounting based on different approaches and describe the gaps and opportunities of developing Islamic accounting theory.

Methods - This study uses meta-aggregation consisting of scoping the focus, selecting previous studies, identifying the data, synthesizing the findings, and producing a synthesized discovery.

Results - Findings discovered three main syntheses. First, constructive approach proposes a pure Islamic accounting. Second, contrary to constructive, pragmatic approach adjusts contemporary accounting with sharia. Third, hybrid approach mediates

Corresponding Author: Nurika Restuningdiah nurika.restuningdiah.fe@um.ac.id

Received: 2 May 2020

Accepted: 4 July 2020

Published: 14 July 2020

Publishing services provided by Knowledge E

(c) Nurika Restuningdiah et al. This article is distributed under the terms of the Commons Attribution License, which permits unrestricted use and redistribution provided that the original author and source are credited.

Selection and Peer-review under the responsibility of the ICIEHI Conference Committee.
S OPEN ACCESS between constructive and pragmatic, which considers Islamic values and social benefits.

Conclusion - Each approach has its opportunities to be developed so that they can go through together to complement each other. This study limits only mapping by literature review. The results implicate to provide ideas to develop Islamic accounting through three approaches identified.

\section{Abstrak}

Tujuan - Sebagian besar cendekiawan Muslim sepakat bahwa akuntansi Islam harus memasukkan Al-Quran dan Hadits, tetapi mereka memiliki perspektif yang berbeda terkait dengan seberapa jauh akuntansi harus di-Islamkan. Oleh karena itu, penelitian ini bertujuan untuk memetakan islamisasi akuntansi berdasarkan berbagai pendekatan; serta mengekslorasi kesenjangan dan peluang mengembangkan teori akuntansi Islam menurut setiap pendekatan tersebut.

Metode - Penelitian ini menggunakan metode meta-agregasi yang terdiri dari menentukan lingkup dan fokus, memilih penelitian terdahulu, mengidentifikasi data, mensintesis temuan, dan menjabarkan temuan hasil sintesis.

Hasil - Temuan menghasilkan tiga sintesis utama. Pertama, pendekatan konstruktif mengusulkan akuntansi Islam murni yang sesuai dengan prinsip-prinsip Islam. Kedua, berkebalikan dengan konstruktif, pendekatan pragmatis melakukan penyesuaian akuntansi kontemporer dengan prinsip syariah. Ketiga, pendekatan hybrid memediasi antara konstruktif dan pragmatis, yang mempertimbangkan nilai-nilai Islam dan manfaat sosial.

Kesimpulan - Setiap pendekatan memiliki peluang untuk dikembangkan bersamasama, yang mana setiap pendekatan dapat saling melengkapi untuk pengembangan akuntansi Islam. Studi ini membatasi hanya pemetaan oleh tinjauan literatur. Implikasi hasil penelitian ini adalah mendorong penelitian selanjutnya untuk mengembangkan akuntansi syariah melalui tiga pendekatan tersebut. 
Keywords: Islamization, Islamic accounting, constructive approach, pragmatic approach, hybrid approach.

Kata Kunci: Islamisasi, akuntansi Islam, pendekatan konstruktif, pendekatan pragmatis, pendekatan hybrid.

\section{Introduction}

In the last ten years, there has been a debate over Islamic accounting. The debate arose not only in the practical realm but up to the domain of accounting theory to conform to the principles of Islam. Many scholars agree that Islamization of knowledge is urgent because incompatibility of knowledge from religion may miseducate Moslems' mind and think (Sartini, 2005). Islamization is a must as stated that Qur'an is relevant to modern sciences (Adebayo, 2015) which consists of redefining, rethinking, re-evaluating, and re-projecting the discipline (Moten, 2004).

However, some writers began to argue from several things. They used different and contrast paradigms in viewing how accounting should be Islamic. Islamic societies face the challenge of reconciling between adopting accounting standards and core Islamic values (Napier, 2007). Some argues adopting standards is more important than the Islamic values, meanwhile some states that Islamic values should be more dominant.

In general, we can categorize into three separate viewpoints. This first viewpoint is an idealistic accounting that Islamic accounting should have different concept and techniques (Velayutham, 2014). This is denied by the second one which tends to be pessimistic of the development of idealistic Islamic accounting because accounting cannot avoid from international standard (Saidat, Al-Ghazzawi, \& Sulihat, 2014). The third viewpoint is the mediated opinion stating that Islamic compliant accounting should be flexible, able to manage transactions containing interest and not, and follow the process of Islamization of sharia law (Mirza \& Baydoun, 1999b).

But, the basic differences of viewpoint on Islamic accounting are still emerging. Each approach defends their opinion and criticizes others. Although Islamic accounting standards have been issued, there were opinions that it seems a convergence with western standards (Centorrino, 2014). Therefore, it is worth to explore various existing opinions on Islamic accounting and map the trends of Islamic accounting theorization.

Meta-aggregation theory is used due to 1 ) there is a shift of fundamental concepts of the Islamic accounting subject because of multi-paradigm and plurality and 2) unknown 
failure possibility of the conception to progress (Zhao, 1991). Besides mapping the Islamic accounting, this study will also identify opportunities for developing the theory.

\section{Literature Review}

Three main viewpoints of Islamic accounting are identified. The first is Islamic accounting should go beyond sharia compliance accounting. It is based on two reasons. First, mostly sharia accounting standards are limited to accounting for sharia transactions only. Sharia accounting has actually been designed which is accompanied by ethics, including the selection of accounting policies based on agreed (aqad) commitments with reference to Islamic principles (Haniffa, Hudaib, \& Mirza, 2008). However, Islamization should not only be in terms of Islamic finance contracts but should also be Islamization of accounting itself. Islamic accounting systems and concepts should be different from the conventional (Velayutham, 2014). Second, Islam is not only limited to sharia, but also faith (aqidah) and ethics (akhlaq).

The second viewed that the role of religion in the preparation of the accounting system is rather low. Accounting is not only based on religious considerations but is the result of all aspects, such as the practical needs and input of interested parties (Badshah, Mellemvik, \& Timoshenko, 2013). Moreover, as we are now in the global economic environment and the fact that capitalist economy dominates, the preparation of accounting standards will not be separated from international standards such as International Accounting Standards (IAS) (Saidat, Al-Ghazzawi, \& Sulihat, 2014).

The third viewpoint is the middle between idealistic and pragmatic. Sharia accounting practices should uphold ethics and avoid fraud (Suryanto and Ridwansyah, 2016). Furthermore, sharia accounting should be able to expose quantitative and qualitative information on how sharia institutions contribute to society (Kamla, 2009).

\section{Methodology}

This study is a meta-study (as a second-order study) that uses secondary data of previous (first-order) studies to be analyzed and gone beyond itself by synthesizing their results. Meta-study is used because this study does not intend to explore the aspects of ontology and epistemology as philosophical research or review an individual study to provide improved inputs as research reviews. This study is a meta-study to understand and develop a discipline, in this case, Islamic accounting theory, by understanding the different views based on different phenomena (Zhao, 1991). This meta-study is more 
than a review as for understanding and advancing the discipline of Islamic accounting, and not only describe "what if" but explore for "what should be" and need reflexivity (Cooper, 1984 in Zhao, 1991).

Review process through meta-aggregation consists of six (6) main stages. First, scoping consists of looking for contrasts, defining and categorizing the focus, gaining idea from empirical studies, using findings from previous researches, formulating review questions, and limiting scope. The first step is explained in the introduction. Second, searching previous studies in an electronic journal and proceeding database, published reviews and working papers in specific study search (Rickinson and May, 2009).

Third, identifying the data to be synthesized (Tufanaru, 2015). To select prior studies, this study considers the appropriateness with Islamic or sharia accounting, but does not limit the year of publication due to the theorization of Islamic accounting is newly conducted in the last twenty years. This study does not also limit geographical scope as the theorization of Islamic accounting are still limited, publication type and research method whereas empirical and quantitative studies contribute in adding justification for the theories, and publication accessibility. This study selects the results of previous writings with several criteria, 1) previous studies obtained are from electronic database, e.g. published articles and reviews in the journal or proceedings, dissertation, and books in English; 2) data collected with specific study search or keywords of "Islamic Accounting Theory, Sharia Accounting, or Critique of Accounting in Islamic Perspective" which discusses Islamic accounting ideas and theories; and 3) articles that discusses sharia accounting starting in 1986 as Islamization of knowledge started to emerge.

In analyzing the prior studies, although this study does not adopt "the best synthesis approach", meta-aggregation approach also require in qualifying prior research. Actually, evaluating the research quality is the most difficult work. Therefore, to overcome this constraint, we use the approach by including the strengths, limitation, and suggestions for further research of each previous study (Rickinson and May, 2009).

Forth, synthesizing the findings from individual studies into categories (Tufanaru, 2015). After considering the research coherence and quality, we need to compare across studies by a) tabulating the studies based on analysis fields, and b) building an analytical map based on the area used. Due to this study uses meta-aggregation approach, we only need to merely compare and not to revisit or interpretation as a meta-ethnography approach. A common strategy in synthesizing is presenting an overview of the main characteristics of each thematic area tabulated; followed by a more detailed discussion of findings, implications, and limitation (Rickinson and May, 2009). 
Fifth, synthesizing categories to produce a synthesized discovery. These synthesized findings represent and include similar findings from each category (Tufanaru, 2015). It brings up a decision in the final results about in what ways, in which detail, and in what findings each category should be (Rickinson and May, 2009).

\section{Results and Discussion}

\subsection{First step: identifying the data to be synthesized}

Forty-four (44) prior studies are selected based on the relevance with the topic of Islamization of knowledge and accounting started from 1986 as it started to emerge since the 1980s which were proposed by several Moslem scholars (Sartini, 2005). This causes issues to Islamize many subjects to be in accordance with Islam, includes accounting.

\subsection{Second step: synthesizing the findings from individual studies into categories}

This study synthesizes from individual studies into categories based on three approaches to Islamize accounting identified by Sartini (2005), constructive approach, pragmatic approach, and hybrid approach. Keywords of each approach are tabulated in Table 1.

TABLE 1: Thematic category of Islamic accounting theory based on different approach

\begin{tabular}{|c|c|c|c|}
\hline & \multicolumn{3}{|c|}{ Approach } \\
\hline & $\begin{array}{l}\text { Constructive } \\
\text { Approach }\end{array}$ & Pragmatic Approach & Hybrid Approach \\
\hline $\begin{array}{l}\text { Findings from } \\
\text { Individual Studies }\end{array}$ & $\begin{array}{l}\text { Normative and } \\
\text { deductive (Gambling } \\
\text { and Karim, 1991). What } \\
\text { Islamic accounting } \\
\text { should be. }\end{array}$ & $\begin{array}{l}\text { Empirical and inductive } \\
\text { approach (Gambling and } \\
\text { Karim, 1991). }\end{array}$ & $\begin{array}{l}\text { It is started with } \\
\text { conventional based } \\
\text { questions, such as } \\
\text { identifying users, } \\
\text { objectives (Sartini, 2005), } \\
\text { assumptions, qualitative } \\
\text { characteristics, and } \\
\text { measurement of Islamic } \\
\text { accounting (Pramuka, } \\
\text { 1998); then develop } \\
\text { characteristics of Islamic } \\
\text { accounting by } \\
\text { incorporating Islamic } \\
\text { ethical (Sartini, 2005; } \\
\text { Bayou, 2017). }\end{array}$ \\
\hline
\end{tabular}




\begin{tabular}{|c|c|c|}
\hline \multicolumn{3}{|c|}{ Approach } \\
\hline $\begin{array}{l}\text { Constructive } \\
\text { Approach }\end{array}$ & Pragmatic Approach & Hybrid Approach \\
\hline $\begin{array}{l}\text { Islamic accounting } \\
\text { consists of accounting } \\
\text { process plus sharia } \\
\text { compliance, and } \\
\text { incorporate divinity } \\
\text { and humanism (Bello, } \\
\text { 2017). }\end{array}$ & $\begin{array}{l}\text { Shariah-ization consists of } \\
\text { accepting, rejecting thing } \\
\text { which is contrary to sharia, } \\
\text { and adjusting the } \\
\text { contemporary accounting } \\
\text { with sharia (Birton, } \\
\text { Triyuwono, Mulawarman, \& } \\
\text { Rahman, 2015; Gambling } \\
\text { and Karim, 1991). }\end{array}$ & \\
\hline $\begin{array}{l}\text { Islamic accounting has } \\
\text { to be developed as } \\
\text { proper accounting } \\
\text { theory, not just use } \\
\text { decision usefulness } \\
\text { approach like } \\
\text { conventional theory } \\
\text { (Majid and Haliding, } \\
\text { 2014). }\end{array}$ & $\begin{array}{l}\text { Islamic accounting } \\
\text { objectives are built based } \\
\text { on contemporary } \\
\text { accounting thought and } \\
\text { adjusted with Islamic values, } \\
\text { as for investor confidence } \\
\text { (Tessema, Garas, \& Tee, } \\
\text { 2017; Namaghi, } \\
\text { Azarberahman, \& } \\
\text { Azarberahman, 2012) and } \\
\text { reducing information cost } \\
\text { (Sarea and hanefah, 2013). }\end{array}$ & $\begin{array}{l}\text { Islamic accounting should } \\
\text { go beyond interest } \\
\text { prohibition and ethical } \\
\text { rhetoric (Kamla, 2009). }\end{array}$ \\
\hline $\begin{array}{l}\text { Baydoun and Willett } \\
(2000) \text { and Sulaiman } \\
\text { (2000) support the use } \\
\text { of Value Added } \\
\text { Statement (VAS) to } \\
\text { provide greater } \\
\text { awareness of the } \\
\text { social. }\end{array}$ & $\begin{array}{l}\text { Institutional parties, culture, } \\
\text { and socio-economic } \\
\text { conditions are the main } \\
\text { roles in harmonizing Islamic } \\
\text { accounting standards } \\
\text { (Ul-Hassan, 2007; Mukhlisin, } \\
\text { Hudaib, \& Azid, 2015) and } \\
\text { shaping accounting } \\
\text { standards, not religion } \\
\text { (Badshah, Mellemvik, \& } \\
\text { Timoshenko, 2013). }\end{array}$ & $\begin{array}{l}\text { Islamic accounting should } \\
\text { go beyond technical and } \\
\text { economics, by } \\
\text { incorporating religious, } \\
\text { cultural, and social aspects } \\
\text { (Haniffa, Hudaib, \& Mirza, } \\
\text { 2008; Haghighat, 2013; } \\
\text { Rustiana, 2016). }\end{array}$ \\
\hline $\begin{array}{l}\text { An official Islamic } \\
\text { accounting can be } \\
\text { built in Islamic } \\
\text { society/environment } \\
\text { which includes Islamic } \\
\text { personalities and } \\
\text { Islamic culture } \\
\text { (Gambling and Karim, } \\
\text { 1986). }\end{array}$ & $\begin{array}{l}\text { Islamic accounting } \\
\text { assumptions are compatible } \\
\text { with normative theory, but } \\
\text { Islamic accounting theory } \\
\text { has no major difference with } \\
\text { positive theory (Namaghi, } \\
\text { Azarberahman, \& } \\
\text { Azarberahman, 2012). }\end{array}$ & $\begin{array}{l}\text { Three interrelated } \\
\text { dimensions of Islamic } \\
\text { accounting should be } \\
\text { manifested in practice, } \\
\text { which are 1) fulfilling } \\
\text { economics wealth within 2) } \\
\text { Islamic worldview (God's } \\
\text { pleasure, worship, halal) } \\
\text { and 3) deploying benefits } \\
\text { on society (i.e. zakah) and } \\
\text { environment (Haniffa, } \\
\text { Hudaib, \& Mirza, 2008). }\end{array}$ \\
\hline $\begin{array}{l}\text { Islamization of } \\
\text { accounting needs time } \\
\text { and commitment from } \\
\text { Moslem society (Majid } \\
\text { and Haliding, 2014) }\end{array}$ & $\begin{array}{l}\text { Islamic accounting has } \\
\text { unique principles and } \\
\text { concept but does not } \\
\text { necessarily need } \\
\text { distinguished accounting } \\
\text { (Ahmed, 1994). }\end{array}$ & $\begin{array}{l}\text { The need for wealth } \\
\text { circulation (Khoramin, } \\
\text { 2012). }\end{array}$ \\
\hline
\end{tabular}




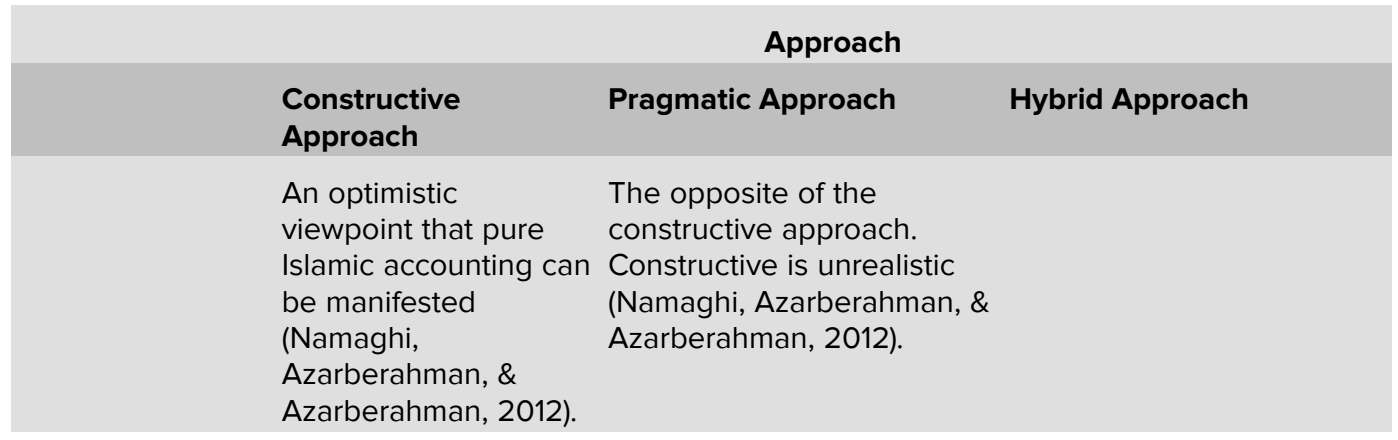

Based on the keywords of each approach showed on Table 1 above, the following is the explanation of each approach.

\subsubsection{Constructive approach}

The constructive approach is a normative and deductive which postulates objectives and definition of Islamic accounting based on Islamic worldview. Developing accounting standards based on the Shari'a principles against not only Islamization of conventional accounting (Gambling and Karim, 1991). In a whole, Islamic accounting consists of all accounting process like identification, recording, summarizing, analyzing, and reporting to users; but in compliance with Shari'a and incorporate divinity and humanism (Bello, 2017). Islamic accounting has to meet Islamic law to develop proper accounting theory, not just direct to decision usefulness approach for the investor like conventional accounting theory (Majid and Haliding, 2014).

Islam rules the matter of possession of properties and assets whereas the main possessor is God, and human is a trustee. This principle should be embedded not only in theory, but it must be proven through behavior such as avoiding maximization of profit, individualism, and self-interest and replacing with a reasonable profit, public interests, justice and equality (Namaghi, Azarberahman, \& Azarberahman, 2012).

Moreover, Baydoun \& Willet (2000) and Sulaiman (2000) support the use of Value Added Statement (VAS) besides the Balance Sheet to be part of Islamic corporate reports. VAS is believed to be able to provide greater awareness of the social impact of the company's activities.

The constructive approach is an optimistic attitude that Islamic conceptual framework with Islamic values and beliefs can be manifested (Namaghi, Azarberahman and Azarberahman, 2012). Islamization of accounting is believed to need time and commitment from all Moslem society (Majid and Haliding, 2014) because official Islamic accounting can be built in Islamic society/environment which includes Islamic personalities of agents and Islamic culture (Gambling \& Karim, 1986). 


\subsubsection{Pragmatic approach}

The pragmatic approach is empirical and inductive which adopts conventional accounting which does not contradict with Islam and exclude those which violates sharia (Gambling \& Karim, 1991). Based on this approach, the concept of Islamic accounting is almost similar to conventional. The difference is only Islamic accounting standards regulate how to record Islamic transaction such as murabaha, mudharaba, etc. Birton, Triyuwono, Mulawarman, \& Rahman (2015) call this approach as shariah-nization. It consists of three proposition, accepting concepts which are in line with sharia, rejecting which is prohibited by sharia, and adjusting the contemporary accounting based on sharia.

Pragmatic approach stands based on several considerations. First is related to the objectives of financial disclosure. Setting Islamic accounting principles contains building objectives in accordance with sharia and comparing with contemporary accounting, or comparing contemporary accounting with sharia and accepting those which are in line with sharia (Badshah, Mellemvik, \& Timoshenko, 2013). To reach a suitable format for Islamic accounting, it needs Islamic advisor and accounting specialist to work together (Saidat, Al-Ghazzawi, \& Sulihat, 2014). One example of this method is objectives are established based on the spirit of Islam and also consider contemporary accounting thought. It is needed to look at the benefits of better financial reporting based on contemporary accounting thought which can reduce adverse selection problems and mitigate the information asymmetry problem (Tessema, Garas, \& Tee, 2017).

Second is related to the users of financial statements. This approach views that accounting standard can be developed to meet the requirements of users in the Islamic economic social environment, both local and global financial market (Alahrash, 2015). This viewpoint seems more logical. But, accounting standard without particular principles can be unclear, so that accounting contents then are adjusted to be compatible with sharia (Namaghi, Azarberahman and Azarberahman, 2012).

Third, the harmonization of accounting standards for Islamic Financial Institutions (IFIs) will pull benefits, such as to create more quality assurance, to avoid misjudgment on financial performance, to enhance financial reporting standardization and comparability among Islamic banks' financial reports across time, to build investors' confidence (Mukhlisin, Hudaib, \& Azid, 2015), and reducing information cost (Sarea and Hanefah, 2013). And also to build accounting, we should refer to indices in developing accounting standards, such as identification of the usefulness, reduction of asymmetry information, economical consideration, and political aspects of the new standard (Scott, 2009). 
Forth is related to the parties who are important in setting accounting standards. Institutional parties, stakeholders, and culture hold more important roles in the harmonization of Islamic accounting standard (Mukhlisin, Hudaib, \& Azid, 2015) and shaping accounting practices than Islam religion (Badshah, Mellemvik, \& Timoshenko, 2013).

Although sharia banks operate in different ways than conventional banks, it does not mean that sharia institutions require accounting that is completely different from the conventional ones (Ahmed, 1994). Discussion of sharia literature is considered to be less contributing to practice, seeing sharia financial institutions operating in global financial markets dominated by Western norms (Napier, 2009). Even Velayutham (2014) explicitly argues that there is no specific division between Western and Islamic accounting, but that there is disclosure whereas Islamic financial reporting is based on unique investment criteria and different accounting standards because of the historical influence of the state, law, religion, and culture. Islamic accounting standard may not be the same as AAOIFI, but is based interpretation of certain Islamic principles issue by each country (Suandi, 2013).

The pragmatic approach also views that the Islamization of knowledge is not as easy as it looks, including accounting. This view is based on a belief that Islamization of knowledge needs many factors conducted together. As UI-Hassan (2007) conclude the obstacles of Islamization process are government support, constitutional and legal aspects, professional practitioners, and socio-economic condition of the country. To set a new philosophical paradigm, it must combine political, social, and cultural environments (Hudaib, 2016).

As history spoke, the earlier normative thinking was captured to design accounting system. But, when accounting scandals occurred, it shifts to positive thinking by exploring the reality of practice (Hudaib, 2016). The example of careful behavior in minimizing risks is by managing reserves. Reserves are made by Islamic banks to smooth and stabilize profit sharing to investors. Reserves are then being criticized because it affects the fairness of financial statements and investors do not have access to reserves (Atmeh and Ramadan, 2012).

Based on this one example, although Islamic accounting assumptions are compatible with normative theory, it is impossible to avoid profit maximization and explanation of positive accounting theory. Therefore, Islamic accounting theory has no major difference with positive theory. In short, a pragmatic approach is the opposite of the constructive approach. It views the constructive as an unrealistic way to choose (Namaghi, Azarberahman and Azarberahman, 2012). 


\subsubsection{Hybrid approach}

Hybrid approach bridges the gap between the constructive and pragmatic approach. It is started with conventional based questions, such as identifying users, accounting objectives (Sartini, 2005), assumptions, qualitative characteristics, and measurement of Islamic accounting (Pramuka, 1998); then develop characteristics of Islamic accounting by incorporating Islamic ethical (Sartini, 2005; Bayou, 2017).

Islamic accounting should more than technical and economics explanation like conventional approach (Haniffa, Hudaib, \& Mirza, 2008). Islamic accounting should consider a behavioral aspect of human being (Ibrahim, 2015) in the form of the norm and societal beliefs (Ahmed, 1994). Both social and economic factors become important considerations in the selection of accounting practices (Mirza and Baydoun, 1999a; Yaya, 2004; Haniffa, Hudaib, \& Mirza, 2008). Moslem managers have roles in balancing between achieving economic and societal interest in applying accounting in an Islamic business environment (Haniffa, Hudaib, \& Mirza, 2008; Rustiana, 2016).

In general economic aspects, Islamic accounting prefers religious, Unity of God, collectivism, reasonable profit, and relative ownership rather than secular, economic rationalism, individualism, profit maximization, and absolute ownership. Islamization is not only changing technical entries but modification of principles (Hameed, 2000). Furthermore, some specific accounting issues are explained, such as: 1) Conservatism (apply methods which are most favorable to community than apply prudent valuation methods and avoid using the most favorable impact on owners); 2) On-going concern (based on contractual agreement between parties than business goes forever); 3) Measuring unit (quantity and monetary based according to zakat calculation than monetary value); 4) Consistency (based on Islamic law than the standards/regulations used by the entity); 5) Materiality (fulfilling all duties before Allah than decision making usefulness); and 6) Users of financial information (identifying socio-economic and religious events and transactions than identifying economic events and transactions) (Lewis, 2001).

Further, Islamic accounting should be more emancipatory than primarily proclaimed social and moral (Kamla, 2009). Islamic accounting improves accounting to a great expand, by internalizing religious, cultural, and social (Haghighat, 2013). Islamic accounting should go beyond interest prohibition and ethical rhetoric (Kamla, 2009). In a more extreme way, third-party should be before our own interest (Abdul-Baki, Uthman, Olanrewaju, \& Ibrahim, 2013). Wealth circulation becomes one concern of Islamic accounting (Khoramin, 2012). 
Therefore, there are three interrelated dimensions of Islamic accounting should be manifested in practice (Haniffa, Hudaib, \& Mirza, 2008; Kamla, 2009). They are fulfilling self-interest or the own needs with seeking God's pleasure as the primary objective in establishing socio-economic justice and deploying benefits on society fairly. Managers not only pursue reasonable profit to generate firms' wealth, but also contribute to create welfare for humans and environment sustainability simultaneously in the frame of Islamic worldview such as tawhid, worship, halal (permissible), community, environment, broader accountability, and public benefit (maslahah) (Abdullah, 2018; Haniffa, Hudaib, \& Mirza, 2008; Ahmed, 1994). Description of Islamic accounting is as follows (Haghighat, 2013):

"Islamic accounting is the process of recognizing, measuring, recording, classifying, summarizing and reporting of lawful financial activities (except amoral activities and against the social principles such as: usury, speculation, gambling, etc.) which are useful for calculation of zakah and khoms, calculation of real profit of Islamic investment operation (such as mudharaba, co-ownership, etc.) and the possibility of decision making for users."

The hybrid approach does not force to build theory from the beginning of the sources (Al-Qur'an and Hadits). As Islamic accounting today cannot be separated from conventional economic climate, conventional accounting represents the behavior of economic agents nowadays; so it needs to start from conventional questions then adjust and incorporate Islamic ethical values.

\subsection{Third step: synthesizing categories to produce a synthesized discovery}

Based on constructive approach, Islamic accounting has to be built as it should be as a proper accounting theory normatively by complying sharia and incorporating divinity and humanism. It needs contribution by Islamic behavior and culture to make an official Islamic accounting with a long commitment.

Contrary to constructive, the pragmatic approach uses contemporary accounting and adjusts with sharia. Conventional viewpoint is used based on an empirical consideration that practical field needs standardized Islamic accounting for reaching investor confidence; religion has no big role in setting a standard, but the government, institutional parties, and culture. Accounting still need to be in accordance with sharia, but it does not really need very different accounting. 
The hybrid approach holds mediating role between constructive and pragmatic approaches. It started with conventional based questions but should go beyond the technical and economic aspects by incorporating religious, cultural, and social aspects.

\subsection{Gap and opportunities among approaches of Islamization of accounting}

Most scholars agree that Islamization of knowledge process is by bringing Al-Qur'an and Hadits into the philosophy of knowledge, whereas Islamic worldview gathered should affect the way we think and behave (Sartini, 2005). Islamic accounting has also been agreed to be in accordance with sharia and create social welfare (maslaha). But, those scholars built their own idea and perspective of Islamizing accounting (Majid and Haliding, 2014) and resulted in various perspective of Islamic accounting.

Based on the above explanations, at the theoretical level, Islamization of accounting is still in debate. First, if the theoretical is still in discussion, at the practical level needs further work such as the needs of appropriate constituent bodies (UI-Hassan, 2007). Second, it is still questionable whether the things that distinguish Islamic accounting than conventional is only in theory or also the practice of recording and preparing financial statements like additional of Value Added Statement (VAS).

However, the constructive approach is seen impossible to reach because an ideal Islamic accounting will not be manifested if the personalities and circumstance are not Islamic. But, if there is cooperation from all parties and support from the chief in an Islamic environment to implement Islamic economics, management, and accounting in a whole; ideal Islamic accounting can be seen something that might be realized. Besides that, adherents of constructive approach believe that Islamic accounting should be built from the philosophical root based on Islamic values. Then, the root will be developed into objectives, assumption, and characteristics. After the basic framework is done, technical accounting will be decided following the framework. Therefore, the constructive approach still can produce Islamic accounting but needs a very long time as it started from the beginning by studying how Islam should rule accounting.

Pragmatic is seen to be the most practical to be applied. As the sharia contracts have been rapidly used by Islamic banking and other financial institutions, Islamic accounting standard is urgently needed. It has to be able to rule the recognition and measurement of sharia contracts adequately and timely. 
Because constructive approach cannot be completed in a short time, the hybrid approach arises. This approach chooses the middle way of thinking, by using conventional questions and reviewing Islamic principles at the same time. It does not stop in setting Islamic accounting standard, but change what is able to change and improve what should be improved using Islamic values gradually without starting from the beginning like the constructive approach.

All approaches can go through together as each has its benefits and complements each other in building Islamic accounting. Hybrid preludes the constructive, but conducts gradual studies to improve the existing pragmatic one.

\section{Conclusion}

Most scholars agree that Islamization of knowledge process include accounting is by bringing Al-Qur'an and Hadits into the philosophy of Islamic accounting as it should be in accordance with sharia and contribute to social welfare. But, scholars built different ideas and perspectives of Islamizing accounting. Based on constructive approach, Islamic accounting has to be built as it should be as a proper accounting theory normatively. The pragmatic approach uses contemporary accounting and adjusts with sharia. The hybrid approach holds mediating role between constructive and pragmatic approaches.

The constructive approach needs cooperation from all parties and support from the chief in an Islamic environment to implement, should be built from the philosophical root into assumption and technical accounting. Pragmatic approach answers the practical need to record and present Islamic contracts. The hybrid approach then arises between constructive and pragmatic. All approaches can go through together as it complements each other. Hybrid preludes the constructive, but gradual studies are conducted to improve the existing one.

\section{Limitation}

Limitation of this study is selecting relevant previous studies through online searching and several hard papers that were found. It can be improved by adding unpublished hard manuscript in a wider range of places. Suggestion for further research is exploring the development of Islamic accounting theory in many aspects both by reviewing literature or conducting a field study. 


\section{References}

[1] Abdul-Baki, Z., et al. (2013). Islamic Perspective of Management Accounting Decision Making Techniques. Journal of Islamic Accounting and Business Research, vol. 4, issue 2, pp. 203-219.

[2] Abdullah, S. (2018). Conventional and Islamic Perspective in Accounting: Potential for Alternative Reporting Framework. International Journal of Economics and Management Engineering, vol. 12, issue 2, pp. 202-205.

[3] Adebayo, R. I. (2015). From Islamicizing the Sciences to Strategizing for Muslims' Scientific Breakthrough. International Journal of Islamic Thought, vol. 7, pp. 25-38.

[4] Ahmed, E. A. (1994). Accounting Postulates and Principles from an Islamic Perspective. Review of Is/amic Economics, vol. 3, issue 2, pp. 1-18.

[5] Al Faruqi, I. R. (1988). Islamization of Knowledge: Problems, Principles and Perspective in Islam. Herndon Virgina: International Institute of Islamic Tought.

[6] Alahrash, O. M. A. (2015). Accounting from the Perspective of Islamic Sharia. South East Asia Journal of Contemporary Business, Economics and Law, vol. 7, issue 1, pp. 1-8.

[7] Atmeh, M. A. and Ramadan, A. H. (2012). A Critique on Accounting for the Mudarabah Contract. Journal of Islamic Accounting and Business Research, vol.3, issue 1, pp. 7-19.

[8] Badshah, I., Mellemvik, F. and Timoshenko, K. (2013). Accounting from a Religious Perspective: A Case of the Central Government Accounting in Islamic Republic of Pakistan. Asian Economic and Financial Review, vol.3, issue 2, pp. 243-258.

[9] Baydoun, N. and Willet, R. (2000). Islamic Corporate Report. Abacus, vol. 36, issue 1, pp. 71-90.

[10] Bayou, M. S. M. S. (2017). The Nature of Islamic Accounting and Methodology Used in Muslim Countries: Practical Application in UAE. In: 18th Asian Academic Accounting Association (FourA) Annual Conference, pp. 192-199. Bali.

[11] Bello, A. (2017). Accounting for Inflation: Arguments of Recognition in Islamic Accounting Standards. In: SHS Web of Conference 34, Vol. 09004.

[12] Birton, M. N. A., et al. (2015). Theory of Shariahization on Conceptual Accounting Framework: A Substantive Theory. Procedia Social and Behavioral Sciences, vol. 211, pp. 723-730.

[13] Centorrino, G. (2014). Harmonization and More International Consistency of Islamic Financial Reporting. Zeszyty Naukowe Uniwersytetu Szczecińskiego Nr 
802, "Finanse, Rynki Finansowe, Ubezpieczenia" Nr 65, Wydawnictwo Naukowe Uniwersytetu Szczecińskiego, Szczecin, S65, vol. 802, pp. 275-288.

[14] Gambling, T. E. and Karim, R. A. A. (1986). Islam and "Social Accounting." Journal of Business Finance \& Accounting, vol. 13, issue 1, pp. 39-50.

[15] Gambling, T., \& Karim, R. A. A. (1991). Business and Accounting Ethics in Islam. London: Mansell.

[16] Haghighat, M. (2013). Component of Islamic Accounting. International Journal of Advanced Studies in Humanities and Social Science, vol.1, issue 4, pp. 305-312.

[17] Hameed, S. (2000). The Need for Islamic Accounting: Perceptions of Its Objectives and Characteristics by Malaysian Muslim Accountants and Accounting Academics. Scotland: University of Dundee.

[18] Haniffa, R., Hudaib, M. and Mirza, A. M. (2008). Accounting Policy Choice within the Shari'ah Islami'iah Framework. In M. D. Bakar, \& E. R. A. Engku Ali (Eds.), Essential Readings in Islamic Finance CERT.

[19] Hudaib, M. (2016). Reflection on Islamic Accounting Research and Methodologies. Journal of Turkish Social Sciences Research, vol.1, issue 2, pp. 40-46.

[20] Ibrahim, A. A. (2015). Historical Evaluation on Islamic Accountancy. International Journal of Business, Economics and Law, vol. 7 issue 1, pp. 11-19.

[21] Ikatan Akuntan Indonesia (IAI). (2007). Kerangka Dasar Penyusunan dan Penyajian Laporan Keuangan Syariah.

[22] Kamla, R. (2009). Critical Insights into Contemporary Islamic Accounting. Critical Perspective on Accounting, vol. 20, pp. 921-932.

[23] Khoramin, M. (2012). The Conceptual Framework of Islamic Accounting. Academic Journal of Accounting and Economic Researches, vol.1, issue 1, pp. 21-30.

[24] Lewis, M. (2001). Islam and Accounting. Accounting Forum, vol. 25, issue 2, pp. 103-127.

[25] Majid, J. and Haliding, S. (2014). The Need for the Islamization of Knowledge in Accounting. Al-lqtishad, vol. 6, issue 1, pp. 11-21.

[26] Mirza, M. and Baydoun, N. (1999). Accounting Policy Choice in an Interest-Free Environment. Working Paper No. 1999-01 4.

[27] Mirza, M. and Baydoun, N. (1999). Do Islamic Societies Need Their Own Accounting and Reporting Standards? Journal of the Academy of Business Administration, vol. 4, issue 2, pp. 39-45. 
[28] Moten, A. R. (2004). Islamization of Knowledge in Theory and Practice: The Contribution of Sayyid Abul A'lā Mawdudi. Islamic Studies, vol. 43, issue 2, pp. 247-272.

[29] Mukhlisin, M., Hudaib, M. and Azid, T. (2015). The Need for Shariah Harmonization in Financial Reporting Standardization The Case of Indonesia. International Journal of Islamic and Middle Eastern Finance and Management, vol. 8, issue 4, pp. 455-471.

[30] Namaghi, D. M., Azarberahman, J. and Azarberahman, A. (2012). Theoretical Bases of Islamic Accounting and Challenges Ahead. International Journal of Commerce, Business and Management, vol. 1, issue 3, pp. 136-139.

[31] Napier, C. (2007). Other Cultures, Other Accountings? Islamic Accounting from Past to Present. In: 5th Accounting History International Conference, Banff.

[32] Napier, C. (2009). Defining Islamic Accounting: Current Issues, Past Roots. Accounting History, vol.14, issues 1-2, pp. 121-144.

[33] Pramuka, B. A. (1998). Accounting in Indonesia - A Study of the Ideological Influences on Western and Islamic Accounting Thought and Practices. Hull: University of Hull.

[34] Rickinson, M. and May, H. (2009). A Comparative Study of Methodological Approaches to Reviewing Literature. York: The Higher Education Academy.

[35] Rustiana, S. H. (2016). The Development of Syariah Accounting in Indonesia. International Journal of Business, Economics and Law, vol. 9 issue 5, pp. 117-123.

[36] Saidat, Z. M. F. Al., Al-Ghazzawi, A. M. and Sulihat, N. A. (2014). Accounting Measurements: Islamic Perspective versus Financial Accounting Perspective. Interdisciplinary Journal of Contemporary Research in Business, vol. 6, issue 2, pp. 362-377.

[37] Sarea, A. M. and Hanefah, M. M. (2013). The Need of Accounting Standards for Islamic Financial Institutions. International Management Review, vol. 9, issue 2, pp. 50-59.

[38] Sartini. (2005). Islamization of Accounting. Jurnal Analisis Bisnis \& Ekonomi, vol. 3, issue 2, pp. 197-203.

[39] Scott, W. R. (2009). Financial Accounting Theory (6 ${ }^{\text {th }}$ ed.). Toronto: Pearson Prentice Hall.

[40] Suandi, A. B. (2013). Islamic Accounting in Indonesia: A Review from Current Global Situation. Retrieved from ebislam.wg.ugm.ac.id/images/pdf/ShogakuKenkyukaKiyo_77_Suandi.pdf.

[41] Sulaiman, M. (2000). Corporate Reporting from an Islamic Perspective. Akuntan Nasional, October issue, p. 18-22. 
[42] Suryanto, T. and Ridwansyah, R. (2016). The Shariah Financial Accounting Standards: How They Prevent Fraud in Islamic Banking. European Research Studies, vol 19, issue 4, pp. 140-157.

[43] Tessema, A. M., Garas, S. and Tee, K. (2017). The Impact of Islamic Accounting Standards on Information Asymmetry. International Journal of Islamic and Middle Eastern Finance and Management, vol.10, issue 2, pp. 170-185.

[44] Tufanaru, C. (2015). Theoretical Foundations of Meta-Aggregation: Insights from Husserlian Phenomenology and American Pragmatism. Adelaide: The University of Adelaide.

[45] Ul-Hassan, M. (2007). The Islamization of the Economy and the Development of Islamic Banking in Pakistan. Kyoto Bulletin of Islamic Area Studies, issue 1-2, pp. 92-109.

[46] Velayutham, S. (2014). "Conventional" Accounting vs "Islamic" Accounting: The Debate Revisited. Journal of Islamic Accounting and Business Research, vol. 5, issue 2, pp. 126-141.

[47] Yaya, R. (2004). Would the Objectives and Characteristics of Islamic Accounting for Islamic Business Organizations Meet the Islamic Socio-Economic Objectives? Jurnal Akuntansi dan Auditing Indonesia (JAAl), vol. 8, issue 2, 141-163.

[48] Zhao, S. (1991). Metatheory, Metamethod, Meta-data-analysis: What, Why, and How? Sociological Perspectives, vol. 34, issue 3, pp. 377-390. 